\title{
Exploring the Concepts of Native-Speakerism and World English Among English Language Learners and Teachers in Addarb University College
}

\author{
Ebtehal Asiri \\ Addarb University College \\ Jazan University \\ Jazan, 89759 \\ Saudi Arabia
}

\begin{abstract}
This study looks at how EFL teachers and learners in Addarb University College in Saudi Arabia respond to the concept of native speakerism and World Englishes. 23 English language teachers, as well as 269 English language students, participated in this study. The findings showed that the participants of this study don't respond to the WE varieties appropriately. it also found that their experiences as EFL teachers and learners in the Saudi context did not affecton their attitudes or abilities identifying World English speakers.
\end{abstract}

Keywords: EFL education/ EFL in Saudi Arabia/ World Englishes/ Native-speakerism

\section{Introduction:}

There is no argument against the fact that recently, English is being used as a lingua franca in most parts of the world. It is also true that English being used in many different parts of the world is not one variety but has many varieties influenced by local languages (McArthur, 2003, 2004; Peng \& Ann, 2004; Tayao, 2004; Wee, 2003; Yang, 2005; Zhang, 2002). It is important and beneficial for EFL teachers and learners in the Saudi context to acknowledge the existence of local varieties of English and to become more aware of the characteristics of varieties of Englishes instead of valuing the Standard English. Choi (2007) claimed that, English teachers have to educate the students with the standard norms and rules of English grammar and vocabulary. However, it's also vital to educate them with the different varieties of Englishes that are practiced and used worldwide in order to be a beneficial member of the globalizing world.

It is important to realize that, the concept of World Englishes needs to be discussed and known not only to English teachers and researchers but also to students to free them from the boundaries and limits of Standard English (Choi, 2007). This paper is meant to explore what do the EFL teachers and learners in Addrab university college think of native-speakerism and World Englishes concepts. Therefore, this study attempts to address the following research questions:

1. How do EFL English teachers and learners in Addarb University College respond to different varieties of World Englishes?

2. To which extent do these learners and teachers value the concept of standard English and native-speakerism?

\section{Literature review}

\subsection{English language teaching and learning in SA}

Throughout history, English language teaching and learning in Saudi Arabia has undergone different factors. These factors have participated in shaping and forming the English language in Saudi Arabia nowadays (Mahboob \&Elyas, 2014, p. 128). Al-Seghayer (2014) pointed out that "English currently asserts several functions and enjoys an eminent status in various sectors at all levels within Saudi Arabia" (p.17). In the same manner, Faruk (2014) proclaimed that English in the Saudi context has been seen as a means through which people could learn different knowledge in sciences, arts and new inventions as well as exchange this knowledge from and to other communities (p. 178).

However, Researchers (e.g., Al-Johani, 2009; Fareh, 2010; Khan, 2011) contended that most of Saudi students graduated from high schools, after learning English for 9 years, with a low level and unsatisfactory English proficiency. Alhmadi (2014) attributed the lack of Saudis' English learning skills to the unsuccessful process of teaching and learning (p. 40). In addition to that, teaching English in Saudi Arabia is considered a "challenging phenomenon" since some of the EFL teachers feel it is difficult to manage the Saudi pedagogical and sociocultural issues that occur during English learning and teaching. 
These difficulties might prevent those teachers from encountering unexpected circumstances that happen during the class and be able to modify the teaching materials to meet learners' needs and class objectives (Shah, Hussain \&Nasseef, 2013, p. 105).

\subsection{The concept of Native-Speakerism}

According to Leung (2005), the concept of native and nonnative have a major role in shaping the "bedrock of transnationalized ELT" even though they are not the determiners of language or language users (as cited in Aneja, 2016, p. 572).So who are the native English speakers (NESs)? Are the Americans, Australians and British people the only native speakers in the world because their parents are Americans, Australians or British respectively? Or because they were born and raised in these countries and they and their family have social identities, ex. socials security numbers and passports. Or because their first language is English? In that case, what about the non American or British who were born and raised in the US or the UK and they speak English with American like or British like accents? What about the non American or British families who send their kids to US or UK schools and their kids acquire and speak English as a first language before they speak their parent's language? (Radwanska-Williams, 2008; Rampton, 1990; AlOmrani, 2008).

Davies (1991) defined native speaker as, "The first language a human being learns to speak is his native language; he is a native speaker of this language" (as cited in Bloomfield, 1933, p. 43). Rampton (1990) claimed that "being born into a group does not mean that you automatically speak the language well, many native speakers of English can't write or tell stories, while many non-native speakers can" (p. 18). Similarly, Modiano (1999) announced that being able to use the English language appropriately and proficiently has nothing to do with one's birth place or "nativeness" since "birth does not determine proficiency in speaking English" (as cited in Al-Omrani, 2008, p. 27). Likewise, Kramsch (1997) argued that NS term is neither a privilege of birth nor of education but "acceptance by the group that created the distinction between native and nonnative speakers" (p. 363). Creese, Blackledge and Takhi, (2014) declared that NESTs have been perceived as a "model, a norm, and a goal" in the field of teaching English as a foreign or second language, which makes them superior to NNESs (p. 938). That means embracing the belief that native speakerist is a privilege self-selected group (Widdowson, 2003) of language teachers, creates the marginalization among the NNESs (Rajagopalan, 2005; as cited in Selvi, 2014, p. 578).

However, Widdowson (1994) argued that the possession of the English language does not belong to the native speakers but to all people who share this language aside from their nativeness. In the same manner, Park (2012) claimed that myths of perceiving native speakers as superiority maintains as a hindrance for nonnative English speaking teachers and learners (as cited in Nuske, 2015, p. 286); native speakers are "positioned as the ultimate exemplars and arbiters of English use" whereas nonnative speakers are, "condemned to perpetual inferiority" (Nuske, 2015, p. 286). Jenkins (2007) announced that English native speakers' models are still the norms of the English language teaching and learning worldwide (p. 239).

\subsection{The concept of world Englishes}

Based on (Kirkpatrick, 2014), Traditionally, the English language had been categorized into certain terms and those terms are:

1. English as a native language (ENL), and it refers to the English that is spoken in its native countries such as USA and UK.

2. English as a second language (ESL), and it refers to the English that is spoken in countries where English is important internationally such as India and Singapore.

3. English as a foreign language (EFL), and it refers to the English that is spoken only in classrooms such as in Saudi Arabia and Korea.

Kachru (1985) characterized the English that is used all over the world into three circles:

The Inner circle, the Outer circle, and the Expanding circle. Under the Inner circle are the countries of Britain, USA, Canada, and Australia, which are seen as a native speakers (NSs). The Outer circle represents the countries that use English as a second language for example, Hong Kong, India, and Singapore. And finally those who use English as a foreign language come under the Expanding circle such as, Brazil, Egypt, and Saudi Arabia (as cited in Alshammari, 2015, p. 366). According to Al-Omrani (2008), the countries that represent the expanding circles are those that never were colonized by any inner circle countries and perceive the significant of English as an international language (p.22), which is the case in Saudi Arabia. These circles are similar to the above categorization of the English language, but the difference is Kachru's circles embrace the varieties of Englishes: The strength of the English language is in presenting the Americanness in its American variety, and the Englishness in its British variety. Let us therefore appreciate and encourage the Third World varieties of English too. 
The individuality of the Third World varieties, such as the Indianness of its Indian variety, is contributing to the linguistic mosaic which the speakers of the English language have created in the English speaking world (Kachru,1976, p. 236).

Bolton (2004) defined the termWorld Englishes as an "an umbrella label covering all varieties of English worldwide and the different approaches used to describe and analyze them" (as cited in Jenkins, 2006, p. 159). World Englishes can also be represented as different terms such as international Englishes, global Englishes, and verities of Englishes (Jenkins, 2006). Using these terms don't mean that there is a standard variety of English, but rather each country has its own English.

\subsection{World Englishes in Saudi Arabia}

English in Saudi Arabia is taught and learned as EFL and it is limited within the traditional boundary of Standard American or British English (Alasmari\& Khan, 2014, p. 317/318). According to Al-Omrani (2008) standard English is, "forms of written and spoken English that is thought to be normative for educated users" (p. 33). Many researchers presented that teaching English within the standard American and British boundaries restricted the teachers' ability to teach and leaners' willingness to learn, which result in having challenges in English classes (Al-Asmri\& Khan, 2014; Alshammari, 2015). Matsuda (2003) claimed that "the international scope of learners' English learning agenda should logically be matched by pedagogical approaches that teach English as an international language (EIL), in part through inclusion of varieties of World Englishes" (p. 719). In other words, being exposed to different types of English is profoundly important not only because those learners might confront with English speakers of Outer or Expanding circles, but also because this exposure will enhance the learners' awareness towards the English language.

Additionally, In addition, Tanghe (2013) stressed that multilingual teachers have a powerful and valuable advantage in classrooms in which they can share their first language with their learners (p. 41/42). In the same manner, Matsuda (2003) argued that teaching English must be connected to thenarratives of its spread in all over the world and the changes in its distinguish shapes and usagesince English is no longer owned by the Inner circle countries and "the assumption of nativespeakerauthority that underlies teaching inner-circle varieties of English puts the other circles inan inferior position to the NSs" (p. 722). Similarly, Sharifian (2009) claimed that English doesn'tbelong to the "West" or any other people but rather it is an international language that belongs toits users (p. 44).

The belief that values the "Standard American and British English", as well as the native English teachers, is considered a hindrance in the English language teaching and learning in Saudi Arabia. Many researchers explained that the aim of reaching the American like or British like level of the language made English learners and teachers lose their own language identity.

Therefore, the dominance of this belief is the reason behind the absence of appreciating varieties of Englishes among the Saudi community.

\section{Methodology}

The main purpose of this study is to explore the degree of enhancing the concept of native-speakerism among EFL teachers and learners in Addarb university college. In addition to that, this study is designed to measure the knowledge of varieties of World Englishes among those teachers and learners. As mentioned above, the English language is taught in Saudi Arabia as Standard American or British English. Therefore, it was predicted that since the EFL teachers and learners have been exposed to the concept of "native-speakerism" throughout the Saudi curriculum, there would be a huge number of upholders to native-speakerism as well as a number of rejecters to World Englishes conception.

The methodological framework of this study is designed as a quantitative study since it could help to cover a considerable amount of people which is more than the qualitative study could do. Creswell (2004) articulated that quantitative research is a translation from human practices into numbers. It has been characterized as numeric, deductive, objective, artificial, and not generalizable (Bavelas, 1995).

\subsection{Participants and Context}

This study aimed to address EFL teachers and learners in Addarb University College. This college is one of the branches ofJazan University and it's located in the South West of Saudi Arabia. Beside the English department, this college includes a preparatory year in which students have to study Intensive English for two semesters. The English department in this College has 6 levels. Students start from level 3 (since the first preparatory year is considered level 1 and 2). Those students are usually selected to join this department according to their GPA at the preparatory year.

The participants of the study were 23 English language teachers (from both the English department and preparatory department) as well as 269 English language students from level 3-8 (their ages ranged from 19-22). All the participants were asked to fill out the questionnaire (Appendix A). 
The questionnaire is consisted of 10 statements and the participants are allowed express their levels of agreement on a 5-point Likert scale: Strongly agree / agree / neutral / disagree / strongly disagree. The neutral point means neither agree nor disagree. As it can be seen in Appendix A that the questionnaire was also translated into Arabic to ensure that all the statements were clear. The collected data was transferred into the Microsoft SPSS computer program to analyze the data.

\section{Results and Findings}

Table (1): Descriptive Statistics (n=292)

\begin{tabular}{lll}
\hline Statements & Mean & Std. Deviation \\
\hline I believe that standard English is either British or American & 4.20 & .963 \\
I believe that English belongs to the UK or the USA & 4.08 & .876 \\
It is British or American English speakers who have right to decide how English should be4.14 & .852 \\
taught and learned & 4.13 & .806 \\
I feel ashamed of my Saudi or (local) accent and try to get rid of it when I speak English & 4.00 & .869 \\
If English is used differently from British or American English, it must be wrong & 3.89 & .895 \\
My Saudi or (local) accent of English prevent me from participating in English discussions & \\
I want a native English speaker teacher to teach me English since his/her English is Standard3.90 & 1.128 \\
English & 3.94 & 1.027 \\
Eventually, I will speak native like English if I study with a native speaker teacher & 3.93 & 1.005 \\
I have heard of the concept World Englishes & 4.02 & 1.034 \\
More lectures should be given on World Englishes and varieties of Englishes &
\end{tabular}

This table shows that the mean of (I believe that standard English is either British or American, I believe that English belongs to the UK or the USA, It is British or American English speakers who have right to decide how English should be taught and learned, feeling ashamed of my Saudi or (local) accent and try to get rid of it when speaking English, If English is used differently from British or American English, it must be wrong, and more lectures should be given on World English and varieties of English were ranged from 4.08 to 4.2.

On the other hand the mean of Saudi or (local) accent of English prevent from participating in English discussions, want a native English speaker teacher to teach English since his/her English is Standard English, Eventually, speaking native like English if one studies with a native speaker teacher were ranged from 3.8 to 3.94.

Table (2): I believe that standard English is either British or American

\begin{tabular}{lllll}
\hline & & & & Cumulative \\
& Frequency & Percent & Percent & Percent \\
\hline Strongly agree & 129 & 44.2 & 44.2 & 44.2 \\
Agree & 121 & 41.4 & 41.4 & 85.6 \\
Neutral & 22 & 7.5 & 7.5 & 93.2 \\
Disagree & 10 & 3.4 & 3.4 & 96.6 \\
Strongly disagree & 10 & 3.4 & 3.4 & 100.0 \\
Total & 292 & 100.0 & 100.0 & \\
\hline
\end{tabular}

This table shows that most of the study group were strongly agree that standard English is either British or American $(44.2 \%)$ and nearly the same of them (41.4\%) were agree that standard English is either British or American.

Table (3): I believe that English belongs to the UK or the USA

\begin{tabular}{lllll}
\hline & & & & Cumulative \\
& Frequency & Percent & Percent & Percent \\
\hline Strongly agree & 96 & 32.9 & 32.9 & 32.9 \\
Agree & 144 & 49.3 & 49.3 & 82.2 \\
Neutral & 38 & 13.0 & 13.0 & 95.2 \\
Disagree & 7 & 2.4 & 2.4 & 97.6 \\
Strongly disagree & 7 & 2.4 & 2.4 & 100.0 \\
Total & 292 & 100.0 & 100.0 & \\
\hline
\end{tabular}

This table shows that most of the study group were agree that English belongs to the UK or the USA (49.3\%) and little less than them (32.9\%) were strongly agree that English belongs to the UK or the USA. 
Table (4):It is British or American English speakers who have right to decide how English should be taught and learned

\begin{tabular}{lllll}
\hline & & & & Cumulative \\
& Frequency & Percent & Percent & Percent \\
\hline Strongly agree & 109 & 37.3 & 37.3 & 37.3 \\
Agree & 133 & 45.5 & 45.5 & 82.9 \\
Neutral & 34 & 11.6 & 11.6 & 94.5 \\
Disagree & 14 & 4.8 & 4.8 & 99.3 \\
Strongly disagree & 2 & .7 & .7 & 100.0 \\
Total & 292 & 100.0 & 100.0 & \\
\hline
\end{tabular}

This table shows that most of the study group were agree that British or American English speakers who have right to decide how English should be taught and learned (45.5\%) and little less than them (37.3\%) were strongly agree that British or American English speakers who have right to decide how English should be taught and learned

Table (5):I feel ashamed of my Saudi or (local) accent and try to get rid of it when I speak English

\begin{tabular}{lllll}
\hline & & & & Cumulative \\
& Frequency & Percent & Percent & Percent \\
\hline Strongly agree & 106 & 36.3 & 36.3 & 36.3 \\
Agree & 127 & 43.5 & 43.5 & 79.8 \\
Neutral & 51 & 17.5 & 17.5 & 97.3 \\
Disagree & 7 & 2.4 & 2.4 & 99.7 \\
Strongly disagree & 1 & .3 & .3 & 100.0 \\
Total & 292 & 100.0 & 100.0 & \\
\hline
\end{tabular}

This table shows that most of the study group were agree that feeling ashamed of the Saudi or (local) accent and try to get rid of it when speaking English (43.5\%) and little less than them (36.3\%) were strongly agree that feeling ashamed of the Saudi or (local) accent and try to get rid of it when speaking English.

Table (6):If English is used differently from British or American English, it must be wrong

\begin{tabular}{lllll}
\hline & & & & Cumulative \\
& Frequency & Percent & Percent & Percent \\
\hline Strongly agree & 87 & 29.8 & 29.8 & 29.8 \\
Agree & 136 & 46.6 & 46.6 & 76.4 \\
Neutral & 56 & 19.2 & 19.2 & 95.5 \\
Disagree & 8 & 2.7 & 2.7 & 98.3 \\
Strongly disagree & 5 & 1.7 & 1.7 & 100.0 \\
Total & 292 & 100.0 & 100.0 & \\
\hline
\end{tabular}

This table shows that most of the study group were agree that If English is used differently from British or American English, it must be wrong (46.6\%).

(29.8\%) of them were strongly agree that If English is used differently from British or American English, it must be wrong.

Table (7):My Saudi or (local) accent of English prevent me from participating in English discussions

\begin{tabular}{lllll} 
& & & & Cumulative \\
& Frequency & Percent & Percent & Percent \\
\hline Strongly agree & 72 & 24.7 & 24.7 & 24.7 \\
Agree & 140 & 47.9 & 47.9 & 72.6 \\
Neutral & 60 & 20.5 & 20.5 & 93.2 \\
Disagree & 15 & 5.1 & 5.1 & 98.3 \\
Strongly disagree & 5 & 1.7 & 1.7 & 100.0 \\
Total & 292 & 100.0 & 100.0 & \\
\hline
\end{tabular}


This table shows that most of the study group were agree that the Saudi or (local) accent of English prevent them from participating in English discussions (47.9\%). Whereas, (24.7\%) of them were strongly agree that the Saudi or (local) accent of English prevent them from participating in English discussions. And (20.5\%) of them were neutral.

Table (8):I want a native English speaker teacher to teach me English since his/her English is Standard English

\begin{tabular}{lllll}
\hline & & & & Cumulative \\
& Frequency & Percent & Percent & Percent \\
\hline Strongly agree & 105 & 36.0 & 36.0 & 36.0 \\
Agree & 105 & 36.0 & 36.0 & 71.9 \\
Neutral & 45 & 15.4 & 15.4 & 87.3 \\
Disagree & 22 & 7.5 & 7.5 & 94.9 \\
Strongly disagree & 15 & 5.1 & 5.1 & 100.0 \\
Total & 292 & 100.0 & 100.0 & \\
\hline
\end{tabular}

This table shows that the strongly agree and agree are equally high for needing a native English speaker teacher to teach English since his/her English is Standard English (36.0\%).

\begin{tabular}{|c|c|c|c|c|}
\hline & Frequency & Percent & Percent & $\begin{array}{l}\text { Cumulative } \\
\text { Percent }\end{array}$ \\
\hline Strongly agree & 101 & 34.6 & 34.6 & 34.6 \\
\hline Agree & 106 & 36.3 & 36.3 & 70.9 \\
\hline Neutral & 61 & 20.9 & 20.9 & 91.8 \\
\hline Disagree & 14 & 4.8 & 4.8 & 96.6 \\
\hline Strongly disagree & 10 & 3.4 & 3.4 & 100.0 \\
\hline Total & 292 & 100.0 & 100.0 & \\
\hline
\end{tabular}

This table shows that there were $(36.3 \%)$ of the study group agreed that speaking native like English will occur if they study with a native speaker teacher. Similarly, (34.6\%) of the study group were strongly agreed that speaking native like English will occur if they study with a native speaker teacher, and $(20.6 \%)$ of them were neutral.

Table (10):I have heard of the concept World Englishes

\begin{tabular}{lllll}
\hline & & & & Cumulative \\
& Frequency & Percent & Percent & Percent \\
\hline Strongly agree & 94 & 32.2 & 32.2 & 32.2 \\
Agree & 121 & 41.4 & 41.4 & 73.6 \\
Neutral & 49 & 16.8 & 16.8 & 90.4 \\
Disagree & 20 & 6.8 & 6.8 & 97.3 \\
Strongly disagree & 8 & 2.7 & 2.7 & 100.0 \\
Total & 292 & 100.0 & 100.0 & \\
\hline
\end{tabular}

This table shows that most of the study group were agree that they have heard of the concept of World Englishes $(41.4 \%)$ and little less than them (32.2\%) were strongly agree that they have heard of the concept World Englishes.

Table (11):More lectures should be given on World English and varieties of English

\begin{tabular}{lllll}
\hline & & & & Cumulative \\
& Frequency & Percent & Percent & Percent \\
\hline Strongly agree & 111 & 38.0 & 38.0 & 38.0 \\
Agree & 112 & 38.4 & 38.4 & 76.4 \\
Neutral & 42 & 14.4 & 14.4 & 90.8 \\
Disagree & 17 & 5.8 & 5.8 & 96.6 \\
Strongly disagree & 10 & 3.4 & 3.4 & 100.0 \\
Total & 292 & 100.0 & 100.0 & \\
\hline
\end{tabular}

This table shows that the strongly agree and agree are nearly equally high for believing that more lectures should be given on World English and varieties of English (38.0\%, 38.4 respectively) of study group. 


\section{Findings and discussion}

From the data it became evident that a large number of the participants strongly value the Standard American or British English, which meant that those had negative attitudes towards the varieties of Englishes even though they have more experience with it as Non-native English speakers who teach/ learn English in an Expanding circle country. Despite the fact that the participants of this study have largely assume they have heard of the concept of World Englishes and they also believe that more lectures should be given on the varieties of Englishes, they still favor and value the standard American and British English. I found this point to be interesting because I had not considered that the participants (who are non-native) would favor the Native English and at the same time be supported to the World Englishes concept.

The results from this research and data show positive attitudes towards Inner Circle varieties of World Englishes. All of the participants within this study were living and studying in Saudi Arabia, which doesn't make it clear why the participants had positive attitudes towards American or British English. Those participants had more exposure to World Englishes varieties, especially Expanding Circle varieties during their teaching or learning English in the Saudi context, which was supposed to create more positive attitudes towards WE varieties.

I believe that these beliefs and values towards the native speakers and the ownership of the English language had been constructed because of the exposure to the Saudi English curriculum, which really enhances the native speakers' standard English, as well as the environment in which the participants live. The Ministry of Education (MOE) had also participated in spreading the beliefs and values towards the ownership of the English language. The MOE in Saudi Arabi is highly controlled the English curriculum and the syllabus, which they designed within the boundaries of Standard American or British English (Al-Asmari\& Khan, 2014). Many researchers illustrated that teaching English within the standard American and British boundaries, the boundaries that MOE assigned, restrict the teachers' ability to teach and learners' willingness to learn, which result in having challenges in English classes (Al-Asmri\& Khan, 2014; Alshammari, 2015). So as the MOE, which is considered one of the major ministries in Saudi Arabia, highly values and appreciates the Standard English and believes that the English language belongs only to the Native countries, it is a fortiori to be a widespread belief among the Saudi society, including learners and teachers, as well. Therefore, I was not surprised when I found out what the participants of this study believe about the English language. That was because they had been encountered these concepts throughout their learning experiences, or their teaching experiences, through the MOE's rules and curriculum.

\section{Conclusion}

It is evident from these findings that the participants do not respond to World Englishes appropriately.Varieties of Englishes concept still unexplored fact in the Saudi society. That's why I believe a large number of the participants were not able to perceive the English language as they should since they are an EFL learner/ teacher in an expanding circle country. It's extremely important to give more lectures and courses that focus on the concept of World Englishes among EFL teachers and learners in the Saudi context. Most importantly, the Saudi MOE has to Design a national EFL curriculum that involves the concepts of varieties of Englishes and Saudi English. As clarified above, the current English curriculum in Saudi Arabia supports the notion of ownership over the English language and that impacts the Saudi English learning and teaching. In addition, there should be different teaching programs and workshops for EFL teachers in Saudi Arabia that address the concepts of native speaker fallacy and varieties of Englishes.

\section{References}

Al-Asmari, A. M., \& Khan, M. R. (2014). World Englishes in the EFL teaching in Saudi Arabia. Arab World English Journal, 5(1), 316-325.

Alhmadi, N. S. (2014). English speaking learning barriers in Saudi Arabia: A case study of TibahUniversity. Arab World English Journal, 5(2), 38-53.

Al-Johani, H. M. (2009). Finding a way forward: the impact of teachers' strategies, beliefs andknowledge on teaching English as a foreign language in Saudi Arabia (Doctoral dissertation, University of Strathclyde). Retrieved from http://oleg.lib.strath.ac.uk:80/R/?func=dbin-jump-full\&object_id=11539

Al-Omrani, A. H. (2008). Perceptions and attitudes of Saudi ESL and EFL students toward native and nonnative English-speaking teachers. (Doctoral dissertation, Indiana University of Pennsylvania). Retrieved fromhttp://gradworks.umi.com/33/03/3303340.html

Al-Seghayer, K. (2014). The four most common constraints affecting English teaching in Saudi Arabia. International Journal of English Linguistics, 4(5), 17. 
Alshammari, A. K. (2015). Developing the English Curriculum in the Kingdom of Saudi Arabia: Possibilities and Challenges. Arab World English Journal, 6(4).

Aneja, G. A. (2016). (Non) native Speakered: Rethinking (Non) nativeness and Teacher Identity in TESOL Teacher Education. TESOL Quarterly, 50(3), 572-596.

Bavelas, J. B. (1995). Quantitative versus qualitative? In W. Leeds-Hurwitz (Ed.), Social approaches to communication (pp. 49-62). New York, NY: Guilford Press.

Bloomfield, L. (1933). Language. New York: Holt, Rinehart, \& Winston.

Choi, Kyunghee. (2007). Study on students' attitude towards World Englishes and non-native English teachers. English Teaching, 62(4), 47-68.

Creese, A., Blackledge, A., \&Takhi, J. K. (2014). The ideal 'native speaker' teacher: Negotiating authenticity and legitimacy in the language classroom. The Modern Language Journal, 98(4), 937-951.

Creswell, J. W. (2004). Educational research: Planning, conducting, and evaluating quantitative and qualitative research (2nd ed.). Upper Saddle River, NJ: Merrill Prentice Hall.

Fareh, S. (2010). Challenges of teaching English in the Arab world: Why can't EFL programs deliver as expected? Innovation and Creativity in Education, 2(2), 3600-3604.

Faruk, S. M. G. (2013). English Language Teaching in Saudi Arabia-A World System Perspective. BuletinulStiintific al UniversitatiiPolitehnica din Timisoara, Seria Limbi Moderne, (12), 73-80.

Jenkins, J. (2006). Current perspectives on teaching world Englishes and English as a lingua franca. Tesol Quarterly, 40(1), 157-181.

Jenkins, J. (2007). English as a lingua franca: Attitudes and identity. Applied Linguistics Series. Oxford: Oxford University Press.

Kachru, B.B. (1976) "Models of English for the Third World: White Man's Linguistic Burden or Language Pragmatics?," TESOL Quarterly 10: 221-39.

Khan, I. A. (2011). Learning difficulties in English: Diagnosis and pedagogy in Saudi Arabia. International Research Journals, 2(7), 1248-1257.

Kirkpatrick, A. (2014). World Englishes. In The Routledge Companion to English Studies (pp. 63-75). Routledge.

Kramsch, C. (1997). Guest column: The privilege of the nonnative speaker. Publications of the Modern language Association of America, 359-369.

Mahboob, A., \&Elyas, T. (2014). English in the Kingdom of Saudi Arabia. World Englishes, 33(1), 128-142.

Matsuda, P. K. (2003). Second Language Writing in the Twentieth Century: A Situated Historical Perspective, in B. Kroll (Ed.), Exploring the Dynamics of Second Language Writing, New York: Cambridge University Press.

McArthur, T. (2003). English as an Asian language. English Today, 19, 19-22.

McArthur, T. (2004). Singapore, grammar, and the teaching of 'internationally acceptable English.' English Today, 20, 13-19.

Nuske, K. (2015). Transformation and Stasis: Two Case Studies of Critical Teacher Education in TESOL. Critical Inquiry in Language Studies, 12(4), 283-312.

Peng, L., \& Ann, J. (2004). Obstruent voicing and devoicing in the English of Cantonese speakers from Hong Kong. World Englishes, 23, 535-564.

Radwanska-Williams, J. (2008). The" native speaker" as a metaphorical construct. Metaphors for learning: Crosscultural perspectives, 139-156.

Rampton, M. B. H. (1990). Displacing the 'native speaker': Expertise, affiliation, and inheritance. ELT journal, 44(2), 97-101.

Selvi, A. F. (2014). Myths and misconceptions about nonnative English speakers in the TESOL (NNEST) movement. TESOL Journal, 5(3), 573-611.

Shah, S. R., Hussain, M. A., \&Nasseef, O. A. (2013). Factors impacting EFL teaching: an exploratory study in the Saudi Arabian context. Arab World English Journal, 4(3), 104-123.

Sharifian, F. (Ed.). (2009). English as an international language: Perspectives and pedagogical issues (Vol. 11). Multilingual Matters.

Tanghe, S. (2013). A Qualitative Critical Study of Collaborative Co-Teaching Practices of English Language Teachers in Public Elementary Schools in South Korea (Doctoral dissertation, Indiana University of Pennsylvania).

Tayao, M. L. (2004). The evolving study of Philippine English phonology. World Englishes, 23, 77-90.

Wee, L. (2003). The birth of a particle: know in Colloquial Singapore English. World Englishes, 22, 5-13.

Widdowson, H. G. (1994). The ownership of English. TESOL Quarterly, 28, 377-389.

Widdowson, H. (2003). Defining issues in English language teaching. Oxford University Press.

Yang, J. (2005). Lexical innovations in China English. World Englishes, 24, 425-436.

Zhang, H. (2002). Bilingual creativity in Chinese English: Ha Jin's In the Pond. World Englishes, 21, 305-315. 